\title{
LAW, STATE AND JUSTICE IN THE PURE THEORY OF LAW:
}

\author{
HANS KELSENT
}

\section{I}

IT is a characteristic element of that primitive interpretation of nature we call animism to imagine a soul, spirit or deity within or behind the phenomena, in order to explain their existence or function, and thus to substitute for a real explanation a reduplication of the world. Why is it that a tree grows and a river flows? Because there is an invisible dryad in the visible tree, a nymph in the river, answered the primitive Greeks, who created the god Helois behind the sun and the goddess Selene behind the moon, thus personifying these things. The tendency to personify has its origin in animism. The progress of natural science consists to a great extent in its emancipation from animism; and if the development of social sciences still lags far behind that of natural science it is due, among other things, to the fact that in this field animistic and hence personifying thinking is not completely exterminated. The Pure Theory of Law considers it as one of its main tasks to free the science of law from the relics of animism, which play a particularly dangerous role whenever jurists operate with the concept of juristic person. If we speak in terms of "person", if we say, a juristic person acts or a juristic person has a legal right or a legal duty, we must always ask what is personified, and try to describe the legal phenomena concerned in terms of legal relations among individual human beings, that is to say in terms of human relations determined by the law.

A typical example of animistic reduplication of the object of knowledge is the dualism of law and state still maintained by traditional jurisprudence and political theory. It can hardly be denied that the law is a social order, that is to say an order regulating the mutual behavior of human beings. An order is a set of rules prescribing a certain human behavior, and that means a system of norms. The saying that the purpose of the law is to establish order is one of the many tautologies used in jurisprudence or, what amounts to the same thing, a misleading pleonasm. It produces the illusion as if there were two things, the law on the one hand, and order on the other hand. But the law is itself the order which those who speak of "law and order" have in mind.

Like any science, the science of law must first of all define its object by differentiating it from other similar objects, in answering the question: what is the law as object of a particular science? Like any science,

* A reply to Bergman, The Commusnal Concept of Lasu, 57 YaLE L. J. 55 (1947).

- $\rightarrow$ Professor of Political Science, University of California. 
the science of law must, in defining its object, proceed from a certain usage of language, from the usual meaning of the word by which its object is designated. One must see whether the social phenomena termed "law" present a characteristic in common distinguishing them from other social phenomena, a characteristic sufficiently significant to constitute a general concept for the rational understanding of social life. If the Pure Theory of Law assumes that coercion is an essential element of law, it does so because a careful examination of the social orders termed "law" in the history of mankind shows that these social orders, in spite of their great differences, present one common element, an element of great importance in social life: they all prescribe coercive acts as sanctions. In defining the concept of law as a coercive order, that is to say as an order prescribing coercive acts as sanctions, the Pure Theory of Law simply accepts the meaning that the term "law" has assumed in the history of mankind. ${ }^{1}$ In defining the law as a coercive order the Pure Theory of Law conceives of the law as a specific social technique. This technique is characterized by the fact that the social order, termed law, tries to bring about a certain behavior of men, considered by the law-maker as desirable, by providing coercive acts as sanctions in case of opposite behavior. ${ }^{2}$

The definition of the concept of law as a coercive order refers to the contents of the rules of law; it means that these rules provide for coercive acts as sanctions. It does not mean that the idea men have of the law exercises psychic coercion upon them, coerces them to conform their behavior to the law. But it cannot be denied that a legal order is considered to be valid only if the human behavior to which this order refers is, by and large, in conformity with the order. If this conformity-in whatever way it may be brought about-is termed effectiveness, then effectiveness is a condition of the validity of the law. But it is no specific element of the concept of law. No social order, not even the one we call morality or justice, is considered to be valid if it is not to a certain extent effective, that is to say if the human behavior regulated by the order does not at all conform to it. It is the effectiveness of a social order that, in the usual language, is called the power or might behind

1. Mr. Bergman raises the objection to the Pure Theory of Law that defining the concept of law as a coercive order "... . is begging the question. How does one know at the outset that what is termed 'positive law' is 'law' at all? It would be more fitting to call such rules 'positive norms." But what if these norms present themselves as "law?" Mr. Bergman refuses to call them law because he understands by law only law that is just. Since the Pure Theory of Law does not pretend that its definition refers to just law but only to what usually is and always was termed law, since the Pure Theory of Law is not interested in knowing whether the law as defined by it is law in the specific sense Mr. Bergman uses this term, there is obviously no begging of the question. See KELSEN, General Theory of Law \& State 18-21 (2d printing 1946) and KetSEN, LAw and Peace in International Relations 3-11 (1942).

2. Kelsen, The Law as a Specific Social Technique, 9 U. of Cur. L. REv. 75 (1941). 
the order. Why a given legal order is actually effective, why men behave lawfully, is difficult to say, because we have no adequate method of ascertaining the motives of lawful behavior. Fear of the sanctions provided by the law, especially in case the execution of the sanctions is centralized, may play a decisive role; but it is not impossible that a legal order, or parts of it, are effective for other reasons. Hence, effectiveness as a condition of the validity of the law must not be confused with coercion as an essential element of the concept of law. ${ }^{3}$

\section{II}

As to the relationship between law and state, it is usual to say that the state is a political community which creates or enforces the social order called law. This statement presupposes that state and law are two different things, the one a community, a body of individuals, the other an order, a system of norms. But what is a community? When do several human beings form a community, when are they members of a community presented as a body? A science of law, I think, is not supposed to take these figures of speech literally. What, then, is their real meaning? The term community seems to indicate that individuals forming a community have something in common. It is evident that not everything individuals have in common constitutes a community. Not all men who have dark hair in common form a community, at least not in the sense that the state is a community. Sometimes one assumes that a community is a community of interests, that is to say that individuals who have interests in common form a community." This is certainly not true. Common interests may be the reason for establishing a community; but not all individuals who have interests in common form a community; and there are communities of individuals that are not at all based on a common interest of these individuals, communities which comprise individuals of quite opposite interests. But to present them as communities of interests is to the ideological advantage of those in whose preponderant interest the communities are established. Those may be a majority or a minority of the individuals who form the community. To identify the concept of community with that of a community of interests means to countenance this ideological interest. A typical example is the definition of the state as a community based on the common interest of its subjects, or as a com-

3. Mr. Bergman rejects the view that sanction is essential to the legal norm, by the statement that he believes that "might cannot make law." This is just the above mentioned confusion. If he would analyze the phenomenon he calls "might," he would probably be more cautious in his statements about the relationship between law and might. $C$ f. the chapters, Psychic Compulsion and Mhotizes of Lazual Bchazior in Kerserr, Gerierul. TheORY of LAW AND State (1946).

4. Thus Mr. Bergman says, "A community arises whenever two or more persons have interests in common." 
munity based on the common interest of its subjects, or as a community established for the purpose of realizing the common interest of its subjects. This definition evidently ignores the fact that the people of a state is, with respect to the real interests of the individuals, not necessarily a homogeneous body, that the people is almost always divided into antagonistic groups of interest, that there is not, and there never was, a state within which there is not a greater or smaller number of individuals whose interests-as they rightly or wrongly understand them-are in direct opposition to those on which this community is established or which this community is realizing. The assertion that the community called state is based on the common interests of its subjects amounts to the doctrine that this community is based on the consent of all its members. It is the old fiction of the social contract. It can be maintained only by the aid of the other fiction that he who remains within the community consents to its order and thus shows that it is in his interest. Qui tacet consentire videtur. This is one of the worst legal fictions invented by the Roman jurists. The statement that the state is a community based on or working for the common interests of all its subjects, is of the same nature as the statement that Plato advocates in his Dialogue Laws: that only the just man is happy, the unjust man unhappy. Of this statement he says that if it is a lie it is a useful lie, for it induces the citizens to obey the law, and that means according to Plato, to be just. Hence the government is justified in making the citizens believe it. ${ }^{5}$

The fact that several individuals have an interest in common does not constitute a community any more than the fact that they have dark hair in common. Individuals form a community only if there exist specific relationships among them; and a legal community exists if these relationships are determined by the law. In an extensive study devoted to this problem I have shown that the inter-individual relations, which constitute the community we call state are legal relations, that it is impossible to determine the unity in the plurality of individuals we call state by a criterion independent of the social order we call the law of the state, to define the state as a meta-juristic entity. ${ }^{\circ}$ As far as I can see, the arguments advanced in that study have never been refuted. The legal character of the community called state is particularly manifest when the state is considered in the relations which usually are assumed to exist between this community as a political body and the law. If we say that the state creates or enforces the law, the state is presented as an acting person. But the state can act only through individual human beings. When may an act, performed by a human being, be interpreted as an act of the state? What is the

5. Plato, Laws II, $661 \mathrm{ff}$.

6. Kelsen, Der Soziologische und Juristische Staatsbegrmf (2d ed. 1928). 
criterion for this imputation of the act of a visible being to the invisible person of the state? The problem of the state is essentially the problem of this imputation. The only possible answer is that an act performed by a human being may be imputed to the state if this act is determined by the legal order in a specific way. As long as no other satisfactory answer to the question as to the criterion for this imputation is available, my thesis that the state as an acting person and as subject of duties and rights is nothing but a juristic construction stands unshaken. That the state creates the law means that human beings in their capacity as organs of the state create the law; and that means that they create the law in conformity with legal rules regulating the creation of the law. That the state enforces the law means that a human being acting as an organ of the state executes a sanction provided for by the law. Human beings performing acts of state are acting as "organs of the state." That is a figure of speech meaning that their acts are imputable to the state, and that necessarily means that these acts are legal acts.

The human relations which, in their sum total, are called a community are always determined by an order regulating the mutual behavior of the individuals concerned. This social order constitutes the community. It is this order that the individuals who belong to the community have in common.. The social order and the community constituted by it are not two different things. An individual, together with other individuals, belongs to a community only in so far as his behavior in relation to the other individuals is regulated by the order. To be a member of the community means nothing else but to be subjected to this order. To avoid the misleading appearance of a dualism of social order and community it would be more correct to say the social order is the community, not the social order constitutes the community.

If the state is a community, it is a legal community. As a community it is the legal order of which we say in a not perfectly correct way that it constitutes the community. Who could deny that the state is a social order? And if this statement is accepted, what other order than a legal order could the state be if-expressed in the usual language-it is essential to the state to have or to establish or to enforce a legal order?

However, to say that the state as a social order is identical with the law is not correct. ${ }^{8}$ Not every legal order is a state. Only a relatively

7. Mr. Bergman does not agree with the statement that the law regulates its own creation, because he understands by law justice. The Pure Theory of Law has never maintained that justice regulates its own creation or that the positive law regulates the creation of justice. But that the process by which positive law is created-legislation, judiciary -is regulated by positive law can hardly be denied.

8. Mr. Bergman erroneously maintains that the Pure Theory of Law identifies the state with the law. I never maintained that the highly decentralized social orders of primitive and international law constitute states. 
centralized legal order is termed a state. The personification of this legal order is the state as an acting person. To take this figure of speech literally, to hypostatize the personification, and then to speak of the state as a thing different from "its" legal order, to imagine the state as the authority, community, or power behind the law-just as Helios was imagined behind the sun, Selene behind the moon-and to make the state the god of the law-this is the relic of animism in jurisprudence and political theory, which the Pure Theory of Law tries to eliminate, because it leads to sham problems and empty tautologies. ${ }^{9}$ It seems to be a fruitless endeavor. For, the political interest in making the people believe in a god of the law is stronger than the interest in a scientific analysis and correct description of the phenomena concerned.

\section{III}

The Pure Theory of Law restricts itself to a structural analysis of positive law based on a comparative study of the social orders which actually exist and existed in history under the name of law. Hence the problem of the origin of the law-the law in general or a particular legal order-meaning the causes of the coming into existence of the law in general or of a particular legal order with its specific content, are beyond the scope of this theory. They are problems of sociology and history and as such require methods totally different from that of a structural analysis of given legal orders. The methodological difference between a structural analysis of the law on the one hand, and sociology and history of law on the other hand, is similar to that between theology and sociology or history of religion. The object of theology is God, presumed to be existing; the object of sociology and history of religion is men's belief in God or in gods, whether the object of this belief does or does not exist. The Pure Theory of Law deals with the law as a system of valid norms created by acts of human beings. It is a juristic approach to the problem of law. Sociology and history of law try to describe and explain the fact that men have an idea of law, different at different times and in different places, and the fact that men do or do not conform their behavior to these ideas. It is evident that juristic thinking differs from sociological and historical thinking.

9. Since Mr. Bergman does not see that the law regulates its own creation, he sticlis to the usual saying, the law is the creature of the political community. Hence he defines the law as "the means by which the political community endeavors to realize its paramount interest in maintaining the peace and order of the area." That the law has the purpose of maintaining peace is true, but that does not constitute an element of the clefinition of the law concept. The question is by what means peace is maintained when it is maintained by the law. If we eliminate the maintenance of peace from this definition as not essential and if we substitute for "community" the order constituting the community, Bergman's definition amounts to the meaningless statements : the law is the means by which the law endeavors to realize the law. 
The "purity" of a theory of law which aims at a structural analysis of positive legal orders consists in nothing else but in eliminating from its sphere problems that require a method different from that appropriate to its own specific problem. The postulate of purity is the indispensable requirement of avoiding syncretism of methods, a postulate which traditional jurisprudence does not, or does not sufficiently, respect. Elimination of a problem from the sphere of the Pure Theory of Law, of course, does not imply the denial of the legitimacy of this problem or of the science dealing with it. The law may be the object of different sciences; the Pure Theory of Law has never claimed to be the only possible or legitimate science of law. Sociology of law and history of law are others. They, together with the structural analysis of law, are necessary for a complete understanding of the complex phenomenon of law. To say that there cannot be a pure theory of law because a structural analysis of the law, restricting itself to its specific problem, is not sufficient for a complete understanding of the law amounts to saying that there can be no science of logic because a complete understanding of the psychic phenomenon of thinking is not possible without psychology. ${ }^{10}$

Like the question of the origin of the law, the question of whether a given legal order is just or unjust cannot be answered within the framework and by the specific methods of a science directed at a structural analysis of positive law. This does not necessarily imply that the question of what is justice cannot be answered in a scientific, and that is to say in an objective way at all. But even if it were possible to decide objectively what is just and what unjust, as it is possible to determine what is an acid and what a base, justice and law must be considered as two different concepts. If the idea of justice has any function at all, it is to be a model for making good law and a criterion for distinguishing good from bad law.

There is, however, in traditional jurisprudence a terminological tendency to identify law and justice, to use the term law in the sense of just law, and to declare that a coercive order which on the whole is effective and therefore a valid positive law, or a single norm of such a social order, is no real or true law if it is not just. This use of the term "law" has the effect that any positive law, or single norm of a positive law is to be considered at first sight as just, since it presents itself as law and is generally called law. It may be doubtful whether it deserves to be termed law, but it has the benefit of the doubt. He who denies the justice of such "law" and asserts that the so-called law is no "true" law, has to prove it; and this proof is practically impossible since there is no objective criterion of justice. Hence the real effect of the termi-

10. This is the answer to Mr. Bergman's categorical statement ". . . that there cannot be a pure theory of law." 
nological identification of law and justice is an illicit justification of any positive law.

There is not, and cannot be an objective criterion of justice because the statement: something is just or unjust, is a judgment of value referring to an ultimate end, and these value judgments are by their very nature subjective in character, because based on emotional elements of our mind, on our feelings and wishes. They cannot be verified by facts, as can statements about reality. Ultimate value judgments are mostly acts of preference; they indicate what is better rather than what is good; they imply the choice between two conflicting values, as for instance the choice between freedom and security. Whether a social system that guarantees individual freedom but no economic security is preferable to a social system that guarantees economic security but no individual freedom, depends on the decision whether freedom or security is the higher value. It is hardly possible to deny that there exists a definite difference between the statement that freedom is a higher value than security, or vice versa, and the statement that water is heavier than wood. There are individuals who prefer freedom to security because they feel happy only if they are free, and hence prefer a social system and consider it just only if it guarantees individual freedom. But others prefer security because they feel happy only if they are economically secure, and hence consider a social system just only if it guarantees economic security. Their judgments about the value of freedom and security and hence their idea of justice are ultimately based on nothing but their feelings. No objective verification of their respective value judgments is possible. And since men differ very much in their feelings, their ideas of justice are very different. This is the reason why in spite of the attempts made by the most illustrious thinkers of mankind to solve the problem of justice, there is not only no agreement but the most passionate antagonism in answering the question of what is just. Quite different is the situation with respect to statements about reality. The statement that water is heavier than wood can be verified by experiment, showing that the statement conforms to facts. Statement about facts are based, it is true, on the perception of our senses controlled by our reason, and hence are in a certain sense subjective too. But the perceptions of our senses are in a much higher degree under the control of our reason than are our feelings, and as a matter of fact nobody doubts that water is heavier than wood. Even if we accept a philosophy of radical subjectivism and admit that the universe exists only in the mind of man, we must nevertheless maintain the difference which exists between value judgments and statements about reality. The difference may be relative only as a difference between degrees of subjectivity ("objective" meaning the lowest possible degree of subjectivity). But the relative difference is considerable enough to justify the differentiation between a judgment about what is just and a state- 
ment about what is the law, the positive law. "Positive" law means that a law is created by acts of human beings which take place in time and space, in contradistinction to natural law, which is supposed to originate in another way. Consequently, the question of what is the positive law, the law of a certain country or the law in a concrete case, is the question of a law-creating act which has taken place at a certain time and within a certain space. The answer to this question does not depend on the feelings of the answering subjects; it can be verified by objectively ascertainable facts, whereas the question of whether a law of a certain country or the decision of a certain court is just, depends on the idea of justice presupposed by the answering subject, and this idea is based on the emotional function of his mind.11

The terminological identification of law and justice is one of the characteristic elements of the natural-law doctrine, which presents justice under the name of "natural" law. Positive law is "law", too; and as long as it is not proved to be at variance with natural law is to be considered as true law. Almost all followers of the natural-law doctrine assume, expressly or tacitly, that there exists a presumption in favor of the conformity of positive with natural law. The historical function of the natural-law doctrine was to preserve the authority of the positive law. The doctrine had, and still has, by and large, a conservative character. It is true that revolutionary movements also used this doctrine

11. That a statement about reality is based on the perception of our senses does not, of course, mean that such a statement is true because men believe in it, as Mrr. Bergman asserts in order to prove that there is no difference between value judgments and statements about reality, since both are "subjective". The statement that the sun revolves around the earth was not true although men believed in it; men believed in it because they erroneously thought it was true. If a statement were true because men believe in it, than two contradictory statements were true at the same time if there were people who believed in the one and also people who believed in the other. This would imply the abandonment of logic. Mr. Bergman seriously maintains that "truth is what man believes," and that the objectivity of his belief is "... its prevalence in the community, ... whether the belief concerns a physical fact or a moral evaluation." Consequently he denies the difference between belief and knowledge, which implies the denial of any difference between religion and science. In this respect, I am afraid, Mr. Bergman has proved too much. But in another respect, too little. His doctrine implies that a subjective value judgment assumes objectivity if the judging subject is a community. He speals of "community belicf," of a community's concept or sense of justice, as if the community were the judging subject. What is meant is that individuals belonging to the community, or the majority of those individuals, have the same subjective value judgment. However, the fact that many individuals render the identical value judgments, cannot change the character of the judgment. Mr. Bergman confuses the objectivity of a judgment with the frcquency of the act of judgment. Besides, by substituting for the individual the personified community as judging subject, nothing is won. As there are many different communities, there are many different "community beliefs" or community value judgments, especially many different community judgments about what is just. In one community a socialistic, in another an individualistic ideal of justice prevails. Then the question arises, which of these different ideals is the right one. And to this question, Mrr. Bergman's philosophy has no answer. 
to justify their demands. But the classic exponents of the natural-law doctrine were by no means revolutionaries. ${ }^{12}$

The presumption in favor of the positive law is sustained by an important consequence of the dualism of natural and positive law. The acts of human beings by which, from the point of view of legal positivism, the law is created, such as custom, legislation, judicial decision, consequently have a constitutive character, and which must be interpreted by natural-law doctrine as merely declaratory. From the point of view of that doctrine the organs of the community do not produce the law, they only re-produce a pre-existing law created by God, nature, human reason, or in some other mysterious way. The organs of the community may, it is true, fail to fulfill their task of finding the law and formulating it in an adequate way, but it must be assumed that, on the whole, they succeed; otherwise there would be no law realized in the world. Besides, who could be more competent to decide what natural law prescribes and whether the positive law conforms to the natural law, the true law, than the organs of the community whose task it is to find this law? To confer this competence not on the organs of the community but exclusively on the subjects supposed to obey the law, would amount to establishing anarchy. As paradoxical as it seems, it is nevertheless a fact that the doctrine which denies that the positivelaw-makers really are what they pretend to be-the creators of the law-has the effect, if not the purpose, of strengthening their authority.

Hence the doctrine of a dual law, the true law created by a mysterious authority, and the positive law a mere reproduction of the former, ap. pears in many disguises. It is, for instance, the basis of Rousseau's distinction between the "general will" (volonté générale) and the "will of all" (volonte de tous). The "general will" is always right, and that means just, because it is always directed at the common interest of the members of the community. The organs of the community, in making law, have only to express the general will. They may or may not succeed; even a decision adopted unanimously or by the majority of the people may fail to express the general will and hence be not binding upon the subjects. ${ }^{13}$ But how does the general will come into existence if not by a unanimous or a majority vote of the people? Who is competent to decide whether in a concrete case the "will of all", especially the will of the majority, is or is not in conformity with the "general will"? There is no answer to this question in Rousseau's classic work, although it is just upon the answer to this question that the applicability of his doctrine depends.

12. Kelsen, Naturrecht und Positives Recht, 2 INTERNational ZEITSCuRuTT FÜR

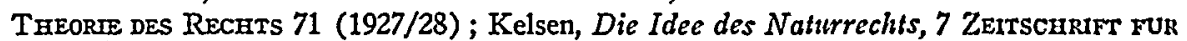
ÖFFENTLICHES RECHT 221 (1927).

13. Rousseau, Soctal Contract, Bk. II, cc. 1-3. 
When Rousseau discusses the voting procedure, however, he states that "the vote of the majority always binds all the rest," that "the general will is found by counting votes," that voting for or against a bill only means deciding whether the suggested bill is or is not "in conformity with the general will, each man, in giving his vote, stating his opinion on that point." To be in the minority "proves" one to be mistaken about what the general will is. ${ }^{14}$ Thus the majority is always right; the introduction of the mysterious entity "general will" and the dualism of the "general will" and the "will of all" amount to a highly problematical justification of a definitive form of government, to the identification of justice with democracy.

Another form of the doctrine of dual law was presented by the German Historical School, allegedly opposed to the natural-law doctrine. The followers of this School started from the basic assumption that the law, like language and religion, is essentially connected with the specific character of a people; an assumption which is highly paradoxical in view of the fact that the German people was forced to give up their own law and their own religion and to adopt the Roman law and the Christian religion, both of which originated with totally different peoples and in documents written in foreign languages. In spite of these historical facts, the German School maintains that the law originates in the spirit of the people (Volksgeist), which is the real creator of the law. Hence even customary law is not created by custom. Cus-

14. RouSSEAU, op. cit. supra note $13, \mathrm{Bk}$. IV, c. 2. This is an open contradiction. In order to attenuate this impression Rousseau does add: ". . . this presupposes indecd, that all the qualities of the general will still reside in the majority. When they cease to do so, whatever side a man may take, liberty [and that means justice] is no longer possible." If the will of the majority is not necessarily in conformity with the general will, and a monarch as well as a popular assembly or a parliament may issue true law, or fail in expressing the general will, how can Rousseau say that the yote of the majority "always" binds the rest, that the general will is "found by counting votes," and that to be in the minority "proves" one to be mistaken about what the general will is? As a matter of fact, Rousseau's Social Contract owes its tremendous success to the fact that it has been understood as a justification of democracy based on the principle of majority will.

It is interesting to note that the dualism of the "general vill" and the "will of all," of true law and positive law, is paralleled by the dualism of the true will of an individual and his actual will. In order to maintain the fiction that an individual who voted against the bill adopted by the majority is still free, although bound by a will that is evidently not his own, Rousseau goes so far as to say that to be in the minority means not only to have a false opinion about what the general will is, but also to have expressed a will which is not one's own will, one's true will. If I vote against the majority and "if my particular opinion had carried the day, I should have achieved the opposite of what was my will." The true will of an individual - but not his actual will-is always in conformity with the general will. Only the individual might not know what the general will is and consequently what his own will is. The individual truly "wills" something that he does not lnow. It is at the price of such fantastic fictions that the positive law-in this case the positive law of democracy-is identified with justice. 
tom is not a law-creating fact; it is only evidence ${ }^{16}$ of pre-existing law created by the mysterious spirit. But custom is considered by the Historical School as absolute reliable evidence; thus customary law is true law and as such preferred to statutory law. As to statutory law, the most prominent representative of this school, Savigny, declared that legislation is a rather problematical function of the state and better omitted. He seriously tried to prove that at his time "the making of a good code was not possible." 16 This was the time when the Code Napoleon, that splendid product of the French Revolution, was issued. But it was against just this Code, against the French Revolution and its successful attempt to replace old by new law, clearly created by legislative acts, that Savigny's theory was directed. Its political tendencies are unmistakable; they explain the hypothesis of an invisible and intangible law-maker, called the "spirit of the people." The people, Savigny says, respect much more "what has not a visible and tangible origin" than "what has been made before our eyes by men of our own kind." 17 Savigny tried to prove that the Roman law was customary law. In maintaining that customary law is created by the spirit of the people and preferable to statutory law, he tried to sustain the authority of the Roman law, which at his time was positive law in Germany.

A similar doctrine is the doctrine of "social solidarity" (solidarite" sociale) as the creator of true law, the "objective law" (droit objectif) presented at the beginning of the twentieth century by the French Sociological School, whose most prominent jurist was Leon Duguit. According to his doctrine the legislative and judiciary organs of the state do not create the law, but only ascertain (constatent) and enforce a pre-existing law originating in the "social solidarity". The positive law is binding only if it conforms to the "objective" law. The authority called "social solidarity" is no less mysterious than the "general will" of Rousseau and the "spirit of the people" of the German historical school. The doctrine that positive law, in order to be binding, must conform to the "objective law" created by the "social solidarity," is applicable only if this doctrine furnishes an answer to the question, who is competent to decide whether in a concrete case positive law is or is not in conformity with the "objective law," the true and just law. This is obviously the decisive question. And it is highly characteristic that Duguit does not even discuss it. He says of the objective law originating in social solidarity that "it is the law of man as a social being .. . man feels it or conceives of it, the scholar formulates it, the positive legislator ascertains it [constate] and secures respect for it." 18 But

15. Savigny, System des Heutigen Romischen Rechts 35 (1840).

16. Savigny, VoM Beruf unsRer Zeit für Gesetzgebung UNd RecuiswisseNSCHAFT 49 (3d ed. 1840).

17. Id. at 43.

18. Duguit, L'Etat, ie Droit Objectif et la Lor Positive 16 (1901). 
what is the "objective law", if one man's feeling or concept of this law differs from that of others, if one scholar formulates it in a different way from another, if the positive legislator ascertains as "objective lav" rules which, according to the feelings or ideas of one who is supposed to obey the positive law, are not "objective law"? It is hardly possible that an individualist and a socialist can agree about what "social solidarity" requires, or what the "objective law", the true or just law, is. Duguit ignores this problem because he simply takes for granted that what he, from his rather individualistic point of view, considers to be objective law is the objective law par excellence.

As for the question who is competent to decide whether a positive law is or is not in conformity with the "objective law," only two answers are possible. The one is that it is within the exclusive competence of the positive law-maker, the legislator and the judge, to decide this question if it is disputed. If so, the positive law will always be declared to be in conformity with the "objective law", and the dualism of the two laws has the effect of a justification of the positive law by a fictitious "objective law." The other possibility is that any individual is competent to decide the crucial question. Then the individuals who are the law-making organs of the community have the same right to decide the question as the individuals who are subjected to the positive law. Duguit says that the positive law is imperative only if it is the expression of the "objective law". In itself, the positive law is not imperative, because those who issue it are human beings just as those at whom the positive law is directed; and since human beings are equal, no individual has any right to command others. ${ }^{10}$ If so, the opinion of an individual acting as legislator or judge is as good as the opinion of an individual to whose behavior the statute or judicial decision refers. If the legislator or judge is of the opinion that the statute or the judicial decision issued by them is in conformity with the "objective law"and if they were not of this opinion they would not have issued the statute or the judicial decision - this opinion must have the same weight as the opinion of an individual who refuses to comply with the statute or the judicial decision, because he thinks that they are not in conformity with the "objective law." The possibility that a positive law "is" objectively in conflict with the "objective law" is practically excluded if there is no objective authority to decide the dispute about the issue. What in reality exists are only contradictory opinions on what the "objective law" is. But the opinion of the governing individuals differs from the opinion of the governed individuals in so far as the former have the power to enforce their opinion; and their competence to enforce a law which they think is in conformity with the "objective law" cannot be abolished by the contrary opinion of the governed subjects,

19. Id. at 426 . 
since the opinion of the governed individuals carries at least no greater authority than the opinion of the governing individuals. Hence, the situation which exists when not only the government but also those subject to the government are competent to judge whether positive law is in conformity with "objective law", is practically not very different from the situation which exists when this judgment is reserved to the government. In both cases the dualism of positive and "objective law" has, just as the dualism of positive and natural law, the effect -if not the purpose - of justifying the one by the other. ${ }^{20}$

These examples perhaps suffice to explain why the Pure Theory of Law insists upon a clear separation of the concept of law from that of justice, be it called natural, true or objective law, and why the Pure Theory of law renounces any justification of positive Law by a kind of super-law, leaving that problematical task to religion or social metaphysics.

20. Mr. Bergman, too, identifies law and justice. He terms "law" only the just law and suggests for unjust law the term "fiat". Consequently the organs of the state, the government, does not make law, but it may make "fiat". "Law" is created by the "articulate majority". But what is the "articulate majority"? If it is the majority of those who, in accordance with the constitution, participate in the popular assembly, or the majority of the elected members of parliament, just law would be identical with democratically created law, and Mr. Bergman's doctrine would be a rather naive identification of justice with democracy. But Mr. Bergman is not as naive as that. He does not define his "articulate majority" as the constitutional majority of a democratically organized community. What he has to say positively of this creator of true law is only that "in any given community the population may be divided between those who articulate [through action or through words] their thoughts and those who do not"; and that "at any given time within a given political community the articulate majority is a precise group, but the society of men has not yet developed measurements fine enough to locate and register this moving force in the body politic." Mr. Bergman is quite right when he admits that the articulate majority "is a nebulous concept at best." But although it is not possible to "locate" and to "register" the articulate majority, this uncontrollable entity is declared by Mr. Bergman to be "the voice of the community" and the organs of government are only "its ears". The government has to "identify" the rules of law issued by this nebulous authority and to "administer them". Since it is impossible to prove that a law issued by the government is not in conformity with that issued by the nebulous law-maker, there must be an assumption in favor of the former. And that is just what Mr. Bergman expressly declares: "the presumption of course is always that the government will follow the law which the community [meaning the "articulate majority"] has established and that, as a consequence, the normative expression of the government will correspond to the normative expression of the community" that is to the true law emanating from the "articulate majority". Mr. Bergman's "articulate majority" is a very primitive, democratically dressed revival of the solidarité sociale of the French sociological school. 